\title{
Management of Persistent Corneal Epithelial Defects with Human Amniotic Membrane-derived Dry Matrix
}

\author{
Sundas Maqsood (iD ${ }^{1,2}$ \\ Kareem Elsawah ${ }^{3}$ \\ Navpreet Dhillon' \\ Shady Soliman ${ }^{3}$ \\ Masara Laginaf ${ }^{2}$ \\ Vaishali Lodhia ${ }^{2}$ \\ Damian Lake' \\ Samer Hamada' \\ Mohamed Elalfy ${ }^{1-3}$
}

'Corneo-Plastic Unit, Queen Victoria Hospital NHS, East Grinstead, UK; ${ }^{2}$ Eye Department, Maidstone and Turnbridge Wells Hospitals, Maidstone, UK; ${ }^{3}$ Cornea Department, Research Institute of Ophthalmology, Giza, Egypt
Correspondence: Mohamed Elalfy

Tel +44 I342 4l 4560

Email m.elalfy@nhs.net
Objective: To report the outcomes of using human amniotic membrane-derived dry matrix (AMDDM) in the management of persistent corneal epithelial defects (PEDs) of various etiologies.

Methods: A cohort study of 84 patients age range 7 to 92 years with 93 PEDs were treated with AMDDM (Omnigen ${ }^{\circledR}$ using OmniLenz ${ }^{\circledR}$ at two centers (Queen Victoria Hospital and Maidstone Hospital) in the UK. The main outcome measures were healing response of PED and time to heal after application of AMDDM.

Results: A total of 106 applications of AMDDM were recorded for 81 patients (52 males, 29 females) with a spectrum of different etiologies. Fifty-eight percent of the eyes showed complete healing, and $28 \%$ showed partial decrease of the size of PEDs with average treatment length recorded as $22.4 \pm 12.3$ days. In patients with limbal stem cell deficiency $(\mathrm{n}=44$; aniridia $=12$, chemical injury $=9$, Stevens-Johnson syndrome $=10), 50 \%$ of PEDs showed complete healing and $27 \%$ showed partial healing. In patients with microbial keratitis ( $\mathrm{n}=21$ ) (bacterial: 13, fungal: 4, herpetic: 3, acanthamoeba: 1) 57\% of PEDs showed complete healing and $33 \%$ were partially healed. In patients with keratoplasty $(n=16), 56 \%$ of PEDs showed complete healing and 31\% were partially healed. Vision remained stable in $59 \%$ and improved in $27 \%$ of the study the population.

Conclusion: AMDDM can be easily applied in the clinical setting and has demonstrated its efficiency as a new tool to treat persistent epithelial defects.

Keywords: persistent epithelial defects, amniotic membrane derived dry matrix, suture less amniotic membrane

\section{Introduction}

Healthy corneal epithelium is integral in preventing corneal infections and protecting the damage to the deeper corneal tissue. It is several layers thick and acts as a barrier via tightly linked cells through hemidesmosomes and gap junctions. The surface integrity alongside the corneal transparency is very important in maintaining the corneal refractive role in vision. The high turnover of the epithelial cells helps heal minor corneal abrasions and acute epithelial defects uneventfully within 7-14 days. ${ }^{1}$ However, in the presence of risk factors like dry eyes, exposure keratopathy, limbal stem cell deficiency and neurotrophic corneal disease the epithelial defects can persist due to failure of reepithelialization mechanism leading to infection, scarring, melting or even perforation. 
An epithelial defect is defined to be persistent (PED) or nonhealing when it fails to show re-epithelialization despite two weeks of standard therapy. ${ }^{1}$ A PED generally involves extension into the stroma, deeper to epithelial basement membrane and thus more so associated with the secondary ulceration, neovascularisation, stromal melting, and scarring. A recent study classified PED as relatively rare condition with an overall incidence of less than 200,000 cases per year in the USA. ${ }^{2}$ Exploring the etiological factors further, the incidence is highest amongst patients with herpetic eye disease, penetrating keratoplasty, and diabetic keratopathy. ${ }^{2}$

Management of PEDs is challenging and requires longer follow-up and controlling the underlying etiologies. Typical first-line treatments range from frequent lubrication, plasma drops, discontinuation of other topical medications, bandage contact lens, punctal occlusion, pressure patching, epithelial debridement lid botulinum toxin injection, and tarsorrhaphy. ${ }^{3}$ In refractory cases, amniotic membrane transplantation (AMT) has been reported to have successful outcomes to promote reepithelialization of PEDs. ${ }^{5-8}$ It is believed that AMT promotes epithelialization by preventing apoptosis and by releasing growth factors which stimulate and support epithelial cells. It physically acts as a substrate for epithelial cell growth. ${ }^{9-11}$ In addition, it is reported to have anti-inflammatory, antimicrobial, antifibrotic and anti-angiogenic properties. ${ }^{12-15}$

Since its first ocular use in 1940, where it was applied with chorion in treating ocular surface chemical burn, ${ }^{16}$ various preservation modalities have been reported to conserve its structure, biochemical, and immunological components. The two main preservation techniques are freeze drying and cryopreservation. ${ }^{17}$ Allen et al have shown a modified preservation process of vacuum-dried amniotic membrane treated with saccharide lyoprotectants (trehalose/raffinose), which has enhanced structural properties and biochemical stability. ${ }^{18}$ Amniotic membrane derived dry matrix $\left(\right.$ Omnigen $\left.^{\circledR}\right)$ represents one such preserved amniotic membrane product (dried amnion treated with raffinose) that is easily transported and stored before application in a clinic setting. It is secured in place on the ocular surface with a bespoke designed bandage contact lens, OmniLenz ${ }^{\circledR}$ (NuVision Biotherapies Limited).

This is the first study to report the efficacy and safety of the use of amniotic membrane-derived dry matrix (AMDDM) in the management of PED of various etiologies.

\section{Methods}

Ninety-three PEDs of 84 patients with various etiologies were studied at a tertiary center (Queen Victoria Hospital,
East Grinstead, $\mathrm{n}=85$ ) and a district general hospital (Maidstone Hospital, $\mathrm{n}=8$ ) in the UK between October 2017 and November 2019. A total of 109 applications of AMDDM were recorded. The study was registered with local institutional review boards at these hospitals and adhered to the tenets of the Declaration of Helsinki. All epithelial defects failing to epithelialize in two weeks with standard therapy were included in the study.

All PEDs presenting at the two centers failing to epithelialize in two weeks with standard therapy were included in the study. Patients with absent or shallow fornixes to fit in a bandage contact lens and fewer than $24 \mathrm{~h}$ of AMDDM application were excluded from the study.

The primary outcome was to establish the healing state of persistent epithelial defects. Complete healing was concluded when the epithelial defect heals completely, whereas intermediate/partial healing was defined where the healing process started with some epithelialization but was slowed or stopped for incomplete epithelial coverage resulting in residual epithelial defect at the end of the course of treatment. A second application of AMDDM was made if the epithelial defect showed partial healing after two weeks, as per recommendation from the manufacturer. Similarly this was repeated in some patients fortnightly which showed a healing response to the treatment.

The secondary outcomes included best corrected visual acuity (BCVA) before and after treatment, etiologies of persistent epithelial defects, concomitant treatments, duration to heal and number of applications of AMDDM per defect.

Omnigen ${ }^{\circledR}$ of size $10 \mathrm{~mm}$ was placed on OmniLenz ${ }^{\circledR}$, which was then applied to the PED after instilling local anesthetic drops (proxymetacaine $0.5 \%$ eye drops) through a sterile technique in the clinic setting. The product detail and step by step construction from Omnigen ${ }^{\circledR}$ to OmniLenz ${ }^{\circledR}$ has been described. ${ }^{19}$ An informed consent was obtained from each patient/parent, or legal guardian if the patient is $<18$ years of age before the application of AMDDM. AMDDM dissolved underneath the securing lens in two weeks, the lens was then removed or replaced after this time period depending on the response of healing.

All patients were covered with topical antibiotics (Chloramphenicol drops $0.5 \%$ ) during the course of treatment or sensitivity specific antimicrobial in patients with microbial keratitis. Due to the complex case mix of the ocular surface diseases in the studies group, tarsorrhaphy was applied as an extra step to facilitate better OmniLenz ${ }^{\circledR}$ fitting in some patients. 
Three patients were excluded from the study, two of these patients had fewer than 24 hs of AMDDM application due to a lens falling out and one patient died during the course of follow-up.

\section{Results}

Ninety persistent epithelial defects of various etiologies received AMDDM application following exclusion criteria. A total of 106 applications of AMDDM were recorded for 81 patients. Seventy-nine patients $(87.7 \%)$ have single application. Seven patients had two applications, two patients had three applications, and one patient had four applications of AMDDM. The epithelial defect requiring four applications was secondary to exposure keratopathy from thyroid eye disease and had partial healing response at the end of the follow-up period. The average number of applications in the patient group achieving complete healing was 1.2.

Mean age of the treated patients was $54.8 \pm 24.2$ years (range: 7-92 years). Fifty-two (64\%) males and 29 (35\%) females with PEDs were treated in the study. One patient with Stevens-Johnson Syndrome was treated bilaterally during the study period (Table 1).

Average treatment length of all patient cohort was recorded to be $22.4 \pm 12.3$ days, whereas in the healed epithelial defects the duration of treatment was $25.3 \pm 13.1$ days.

Table I Demographics of the Patient Cohort

\begin{tabular}{|l|c|c|c|}
\hline & $\begin{array}{c}\text { Number } \\
\text { of Patients }\end{array}$ & $\begin{array}{c}\text { Number of } \\
\text { Applications }\end{array}$ & $\begin{array}{c}\text { Number } \\
\text { of Defects }\end{array}$ \\
\hline $\begin{array}{l}\text { Overall participant } \\
\text { population }\end{array}$ & 81 & 106 & 90 \\
\hline Gender & 52 & 68 & 57 \\
Male & 29 & 38 & 33 \\
Female & 38 & 56 & 39 \\
\hline Laterality & 42 & 48 & 49 \\
Left & 1 & 2 & 2 \\
Right & & 23 & 21 \\
Bilateral & 21 & 3 & 3 \\
\hline Infection & & & \\
\hline Removed & 3 & & \\
Records & & & \\
\hline
\end{tabular}

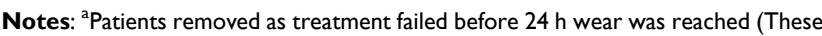
patients are not included in the overall participant population due to their withdrawal.)
The patients were followed-up for $121.9 \pm 68.5$ days from the day of application.

The indications of AMDDM, number of patients and mean treatment length are shown in (Table 2). Limbal stem cell deficiency (LSCD) was present in 44/81 (48.9\%) patients with a mean length of treatment $24.3 \pm 11.7$ days. Aniridia accounted for $12(27.3 \%)$ of the patients with (LSCD), 9 (20.5\%) patients had chemical injury, 10 (22.7\%) had the diagnosis of Stevens-Johnson Syndrome. The remaining $10 \%$ of patients had herpes simplex, radiotherapy and rosacea as the cause of LSCD. Twenty-one defects of 15 patients were secondary to microbial keratitis with a mean treatment length of $21.1 \pm 15.8$ days. Thirteen epithelial defects (62\%)

Table 2 Persistent Epithelial Defect Indications for All Patients and the Duration of Amniotic Membrane-derived Dry Matrix Treatment (Days)

\begin{tabular}{|c|c|c|c|}
\hline Indication Causing PED & $\begin{array}{l}\text { Patients } \\
\text { n (\%) }\end{array}$ & $\begin{array}{c}\text { Mean } \\
\text { OmniLenz }{ }^{\circledR} \\
\text { Treatment, } \\
\text { Days }\end{array}$ & $\begin{array}{c}\text { Standard } \\
\text { Deviation } \\
( \pm)\end{array}$ \\
\hline I. LSCD & 44 (48.9) & 24.3 & 11.7 \\
\hline Aniridia & $12(27.3)^{\mathrm{a}}$ & 19.5 & 8.8 \\
\hline Chemical Burns & $9(20.5)$ & 23.8 & 16.3 \\
\hline Following Keratoplasty & I (2.3) & 28 & - \\
\hline Herpes Simplex Keratitis & $3(6.8)$ & 21.3 & 6.4 \\
\hline Radiotherapy & $3(6.8)$ & 25.3 & 11.2 \\
\hline Rosacea & $3(6.8)$ & 36.6 & 20.8 \\
\hline Stevens-Johnson Syndrome & $10(22.7)$ & 26.1 & 8.3 \\
\hline $\begin{array}{l}\text { 2. Exposure keratopathy, } \\
\text { proptosis, thyroid eye } \\
\text { disease }\end{array}$ & $4(4.4)$ & 22.5 & 3.9 \\
\hline $\begin{array}{l}\text { 3. PED due to PK, DALK or } \\
\text { DSAEK }\end{array}$ & $16(17.8)$ & 23.1 & 13.1 \\
\hline PK & $9(56.3)^{\mathrm{a}}$ & 26.0 & I4.1 \\
\hline DALK & $4(25.0)$ & 23.5 & 11.4 \\
\hline DSAEK & $3(18.8)$ & 14.7 & 13.0 \\
\hline 4. Microbial keratitis & $15(16.7)$ & 21.1 & 15.8 \\
\hline $\begin{array}{l}\text { 5. PED post-photorefractive } \\
\text { keratectomy }\end{array}$ & $\mathrm{I}(\mathrm{I} . \mathrm{I})$ & - & - \\
\hline 6. Neurotrophic cornea & $4(4.4)$ & 7.3 & 4.5 \\
\hline $\begin{array}{c}7 \text {. Bilateral anterior segment } \\
\text { dysgenesis }\end{array}$ & $2(2.2)$ & 30 & 7.1 \\
\hline 8. Fuchs' endothelial dystrophy & $2(2.2)$ & 22.5 & 20.6 \\
\hline 9. Other & $5(5.5)$ & 21.2 & 10.2 \\
\hline
\end{tabular}

Note: ${ }^{\text {P}}$ Percent of cases within each indication.

Abbreviations: PED, persistent epithelial defect; LSCD, limbal stem cell deficiency; PK, penetrating keratoplasty; DALK, deep anterior lamellar keratoplasty; DSAEK, descemet stripping automated endothelial keratoplasty. 
Table 3 Persistent Epithelial Defects Secondary to Microbial Keratitis Group

\begin{tabular}{|l|c|c|c|}
\hline $\begin{array}{l}\text { Type of } \\
\text { Infection }\end{array}$ & $\begin{array}{c}\text { Number } \\
\text { of } \\
\text { Defects }\end{array}$ & $\begin{array}{c}\text { Percentage of } \\
\text { Infected } \\
\text { Defects (\%) }\end{array}$ & $\begin{array}{c}\text { Percentage } \\
\text { of All } \\
\text { Defects (\%) }\end{array}$ \\
\hline Bacterial keratitis & 13 & 61.9 & 15.1 \\
\hline Fungal keratitis & 4 & 19.0 & 4.3 \\
\hline Herpetic keratitis & 3 & 14.3 & 3.2 \\
\hline $\begin{array}{l}\text { Acanthamoeba } \\
\text { keratitis }\end{array}$ & 1 & 4.8 & 1.1 \\
\hline Combined & 21 & - & 22.6 \\
\hline
\end{tabular}

had bacterial keratitis, four were fungal, three were herpetic and one had Acanthamoeba keratitis (Table 3). In the infectious keratitis group $(\mathrm{n}=21)$, AMDDM was used alongside fortified antibiotic cover, which was stopped once the infection started to show signs of suppression to promote epithelial healing.

Sixteen patients (17\%) had PEDs secondary to corneal transplant $(\mathrm{PK}=9$, $\mathrm{DALK}=4$, $\mathrm{DSAEK}=3)$. Four patients had neurotrophic corneas and two patients had bilateral anterior segment dysgenesis. Other patients (5.4\%) had diagnosis of Salzmann's nodular degeneration, band keratopathy, keratoconjunctivitis, and postLASIK PEDs.

Overall $58 \%$ of the PEDs healed completely during the study period, $28 \%$ were partially healed and $13.98 \%$ patients showed no improvement (Table 4). Limbal stem cell deficiency group had $50 \%$ complete healing of the defects, $27 \%$ partially healed, $22 \%$ showed no improvement. Fifty-seven percent of the infected cases $(n=21)$ showed complete healing while $33 \%$ were partially healed. Fifty-six percent of the postcorneal transplant patients $(\mathrm{n}=16)$ showed complete recovery while $31 \%$ were partially recovered. Seventyfive percent of the neurotrophic corneas $(n=4)$ were completely healed whereas the rest (25\%) were partially healed.

Best corrected vision (BCVA) was secondary outcome measure, with results shown in Figure 1. Eighty-four percent of the patient's vision remained stable $(n=48)$ or improved $(n=22)$. Only $15 \%$ of patients were worse off with their BCVA at the end of treatment period. Overall mean pretreatment BCVA was recorded as $1.74 \pm 0.73$ LogMAR compared to posttreatment BCVA of $1.64 \pm 0.79$ LogMAR.

Concomitant treatments and overall duration of treatment length with AMDDM are shown in (Table 5). Eighty-nine percent of the PEDs were treated with topical antibiotics and $69 \%$ had topical steroid treatment

Table 4 Overall Healing Outcomes for Patients with Persistent Epithelial Defects Treated with Amniotic Membrane-derived Dry Matrix

\begin{tabular}{|c|c|c|c|}
\hline & $\begin{array}{c}\text { Completely Healed Defects } \\
\text { n (\%) }\end{array}$ & $\begin{array}{l}\text { Partially Healed } \\
\text { Defectsn (\%) }\end{array}$ & $\begin{array}{c}\text { Defects with No Improvement } \\
\text { n (\%) }\end{array}$ \\
\hline Overall $(n=90)$ & $57(63.3)$ & $21(23.3)$ & $12(13.3)$ \\
\hline Infected patients $(n=2 I)$ & $12(57.1)$ & $7(33.3)$ & $2(9.5)$ \\
\hline Following surgical graft $(n=16)$ & $9(56.3)$ & $5(31.3)$ & $2(12.5)$ \\
\hline PK $(n=9)$ & $6(66.7)$ & $2(22.2)$ & $I(I I . I)$ \\
\hline DALK $(n=4)$ & $2(50.0)$ & $2(50.0)$ & $0(0.0)$ \\
\hline DSAEK $(n=3)$ & I (33.3) & I (33.3) & I (33.3) \\
\hline LSCD $(n=44)$ & $24(58.5)$ & $9(22.0)$ & $8(19.5)$ \\
\hline Aniridia $(n=12)$ & $7(58.3)$ & $\mathrm{I}(8.3)$ & $4(33.3)$ \\
\hline Chemical burns $(n=10)$ & $6(66.7)$ & $I(I I . I)$ & $2(22.2)$ \\
\hline Following Keratoplasty $(n=I)$ & I $(100.0)$ & $0(0.0)$ & $0(0.0)$ \\
\hline Herpes simplex keratitis $(n=3)$ & $2(66.6)$ & I (33.3) & $0(0.0)$ \\
\hline Radiotherapy $(n=3)$ & $2(66.6)$ & I (33.3) & $0(0.0)$ \\
\hline Rosacea $(n=3)$ & $2(66.6)$ & $0(0.0)$ & I (33.3) \\
\hline Stevens $-J o h n s o n$ Syndrome $(n=10)$ & $2(20.0)$ & $5(50.0)$ & $3(30.0)$ \\
\hline Neurotrophic cornea $(n=4)$ & $3(75.0)$ & I (25.0) & $0(0.0)$ \\
\hline
\end{tabular}

Abbreviations: PED, persistent epithelial defect; LSCD, limbal stem cell deficiency; PK, penetrating keratoplasty; DALK, deep anterior lamellar keratoplasty; DSAEK, descemet stripping automated endothelial keratoplasty. 


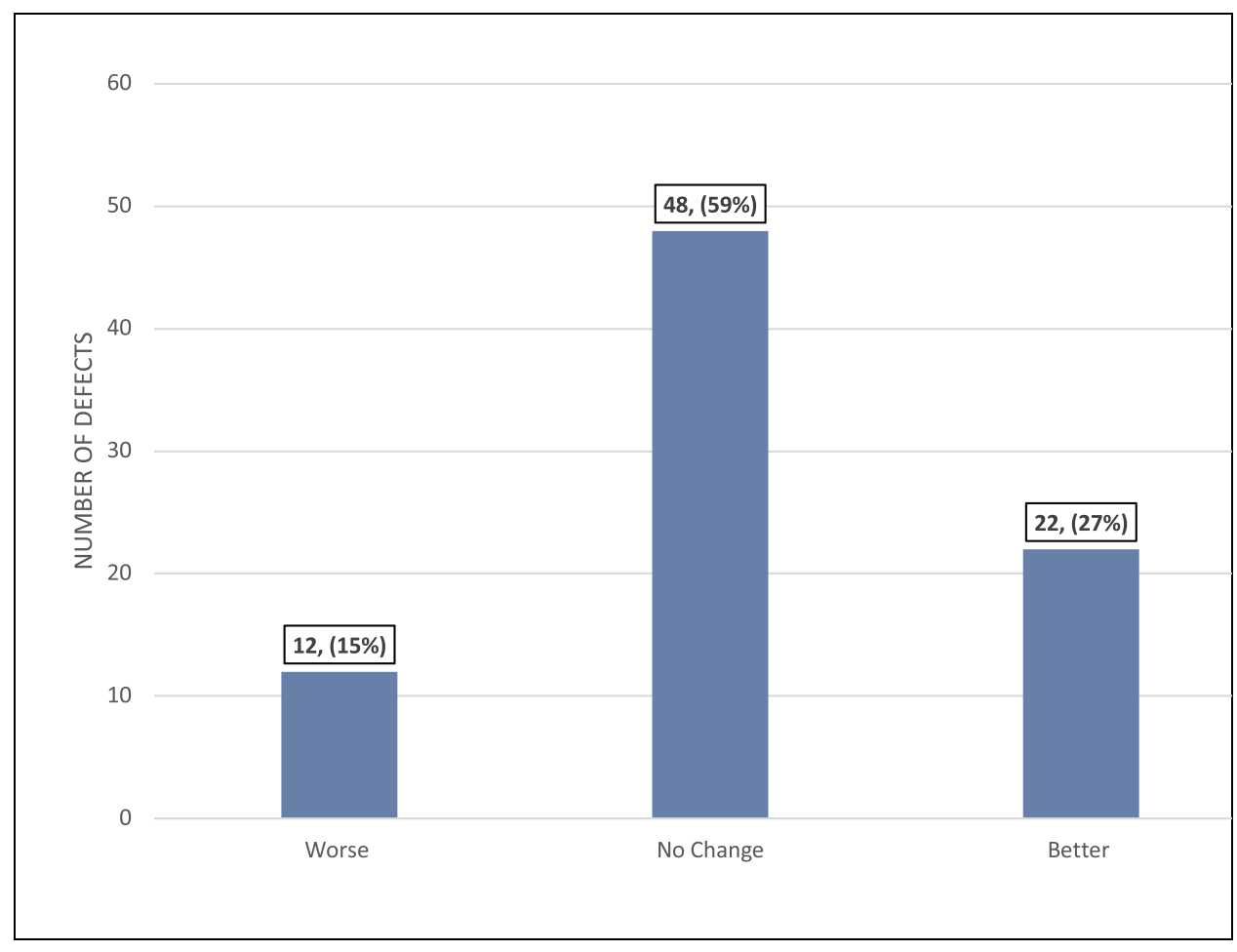

Figure I Data corresponding to the change in best correct visual acuity (BCVA) of all defects treated with amniotic membrane-derived dry matrix.

simultaneously at the time of treatment. Twenty-five PEDs were treated with topical $(17.2 \%)$ or systemic $(9.7 \%)$ immunotherapy. Eighteen epithelial defects $(19.4 \%)$ were treated with plasma eye drops. Eight patients had simultaneous tarsorrhaphy (seven lateral, one medial) when treated with AMDDM for better lens fit, for which $56 \%(\mathrm{n}=5)$ showed complete healing and $22 \%(n=2)$ were partially healed at the end of the treatment period.

Overall, $14 \%(n=14)$ of the PEDs which showed no improvement ended up having complete tarsorrhaphy $(n=5)$ and limbal stem cell transplant $(n=6)$ from the follow-up data. Table 6 shows the follow-up care of patients with partial or no healing. Owing to the small number of patients in each group in the study, it was not feasible to make accurate inferences on the factors associated with failure of the healing of these epithelial defects.

\section{Discussion}

Persistent epithelial defects can be caused by primary ocular surface disorders (keratoconjunctivitis sicca, neurotrophic keratitis), limbal stem cell deficiency disorders (chemical injury, Stevens- Johnson syndrome), systemic diseases (ocular cicatricial pemphigoid, toxic epidermal necrolysis) and are the most challenging condition to treat. These disorders can cause significant damage to the corneal stem cells and epithelial basement membrane. ${ }^{20}$ Various studies have shown the presence of intact epithelial basement membrane promoting epithelial cell migration, ${ }^{21}$ adhesion ${ }^{22}$ and differentiation. ${ }^{23}$ Human placental amniotic tissue is composed of a single epithelial cell layer, basement membrane and avascular stroma. ${ }^{24}$ This structure provides excellent substitute for damaged basement membrane, enhancing the healing capabilities of such diseased corneas. ${ }^{9-11}$

A large number of studies have reported the outcomes of sutured amniotic membrane in dealing ocular surface diseases. It has proven to be a more viable option with the advancement in biological adhesives ${ }^{25,26}$ and suture-free amniotic membrane devices such as ProKera (BioTissue, USA) ${ }^{26-31}$ Both these alternatives prevent suture-related intraoperative and post operative complications. ${ }^{32,33}$

Though both ProKera and Omnigen both involve sutureand adhesive-less application, ProKera is a self-retained cryopreserved amniotic membrane whilst Omnigen ${ }^{\circledR}$ is vacuum dehydrated and applied and secured by a bespoke bandage contact Lens $\left(O m n i l e n z^{\mathbb{R}}\right)$. Treatment with raffinose before dehydration has been shown to preserve the structural and biochemical properties of amniotic membrane over extended periods leading to reducing storage and 
Table 5 Concomitant Medications and Average Duration of Treatment of Amniotic Membrane-derived Dry Matrix

\begin{tabular}{|l|c|c|c|}
\hline $\begin{array}{l}\text { Concomitant } \\
\text { Medication }\end{array}$ & $\begin{array}{c}\text { Defects } \\
\mathbf{n}(\%)\end{array}$ & $\begin{array}{c}\text { Duration of } \\
\text { OmniLenz }{ }^{\circledR} \\
\text { Treatment (days) }\end{array}$ & $\begin{array}{c}\text { Standard } \\
\text { Deviation }\end{array}$ \\
\hline $\begin{array}{l}\text { Topical } \\
\text { antibiotics }\end{array}$ & $83(89.2)$ & 24.6 & 15.4 \\
\hline Topical steroids & $62[68.8)$ & 25.0 & 15.8 \\
\hline $\begin{array}{l}\text { Topical } \\
\text { immunotherapy }\end{array}$ & $14(17.2)$ & 25.2 & 10.8 \\
\hline $\begin{array}{l}\text { Systemic } \\
\text { immunotherapy }\end{array}$ & $9(9.7)$ & 26.2 & 16.7 \\
\hline $\begin{array}{l}\text { Lubricating eye } \\
\text { drops }\end{array}$ & $38(43.0)$ & 24.1 & 12.5 \\
\hline $\begin{array}{l}\text { Antiglaucoma } \\
\text { medications }\end{array}$ & $11(11.8)$ & 19.6 & 15.2 \\
\hline Tarsorrhaphy & $8(8.6)$ & 22.7 & 16.7 \\
\hline $\begin{array}{l}\text { Plasma eye } \\
\text { drops }\end{array}$ & $17(19.4)$ & 21.8 & \\
\hline
\end{tabular}

transport restrictions and improving costs. ${ }^{18}$ This form of amniotic membrane has shown improved healing response and wound closure rates (84-86\%) at the end of first week of treatment. It acts on cell proliferation by releasing biochemical factors like EGF and TGF- $\beta 1$ in greater quantities than that compared to cryopreserved amnion which helps in proliferation and reducing apoptotic activity at cellular level. ${ }^{18}$

ProKera and OmnLenz ${ }^{\circledR}$ application of Omnigen ${ }^{\circledR}$ are both office-based procedures. ProKera is currently not available in UK for clinical use.

This study demonstrated the efficacy and safety of AMDDM in treating PEDs of various etiologies. Sixtythree percent of the patients in the overall sample epithelialized within 25 days and remain epithelial defect free for a mean of $121 \pm 68.5$ days follow-up period. Our results
Table 6 Follow-up Care for Patients with Partial or No Healing

\begin{tabular}{|l|c|}
\hline Follow-up Care & $\begin{array}{c}\text { No. of } \\
\text { Defects }\end{array}$ \\
\hline I. Surgical intervention required & 14 \\
Amniotic membrane transplantation & 3 \\
Entropion correction & $\mathrm{I}$ \\
Evisceration & $\mathrm{I}$ \\
Limbal stem cell transplantation & 3 \\
Orbital decompression & 1 \\
Penetrating keratoplasty & 5 \\
\hline 2. Clinical judgement-alternative medical & 16 \\
management & 12 \\
Bandage contact lens & 3 \\
\hline ProKera & 3 \\
\hline 3. Follow-up lost & \\
\hline
\end{tabular}

showed better overall healing rates in comparison to the study published by Suri et al for 35 eyes treated with ProKera ( $40 \%$ complete healing and $22 \%$ partial healing). ${ }^{34}$

Most of the reported studies on ProKera are with a much smaller number of patients. ${ }^{25,28-31}$ Comparison of our results of each group in the reported literature on ProKera by Suri et $\mathrm{al}^{34}$ is outlined in Table 7 .

Overall, AMDDM was used in this study for a wide range of etiologies. This is the first ever study to report the results in a pilot study for its use in PEDs. AMDDM proved to have easy application in the outpatient clinic setting with no storage restrictions. It was very well tolerated by the patients and had moderate to excellent results based on the indication. The short to mid-term follow-up demonstrated good results overall and in all categories of indications. This study also confirms its use in patients following procedures like EDTA chelation, refractive keratectomy and PED following keratoplasty. The study showed improved healing response of epithelial defects with infective keratitis and also its safety when used as an adjunct to fortified topical antimicrobial

Table 7 Comparison Between the Studied Data Set and the ProKera Results in the Suri et al, 20I3 Study

\begin{tabular}{|l|c|c|c|c|}
\hline & \multicolumn{2}{|c|}{ Number of Patient Defects } & \multicolumn{2}{c|}{ Percentage of Completely Healed Patients } \\
\hline & OmniLenz® & ProKera & OmniLenz® & ProKera \\
\hline Overall participant population & 90 & 35 & 63.4 & 40 \\
\hline Infected patients & 21 & 9 & 57.1 & 22.2 \\
\hline Chemical injury & 9 & 5 & 66.7 & 60 \\
\hline
\end{tabular}


treatment. Further studies with a larger number patients are required to draw more conclusive results in this subgroup. The retrospective nature of the study and short to moderate term follow-up are two limitations of the study. Future prospective studies in the presence a of control group and longer-term follow-up would be useful to assess its efficacy.

\section{Ethics Approval and Informed Consent}

The study was approved as a prospective audit by local institutional review boards at Queen Victoria Hospital and Maidstone Hospital NHS Trusts, UK and adhered to the Declaration of Helsinki.

All participants provided informed consent for participation in the study.

\section{Author Contributions}

All authors made a significant contribution to the work reported, whether that is in the conception, study design, execution, acquisition of data, analysis and interpretation, or in all these areas; took part in drafting, revising or critically reviewing the article; gave final approval of the version to be published; have agreed on the journal to which the article has been submitted; and agree to be accountable for all aspects of the work.

\section{Funding}

There is no funding to report.

\section{Disclosure}

The authors report no conflicts of interest in this work.

\section{References}

1. Dahlgren MA. Persistent epithelial defects. In: Albert DM, Miller JW, Editors. Albert \& Jakobiec's Principles and Practice of Ophthalmology. Philadelphia: Elsevier; 2008:749-759.

2. Wirostko B, Rafii M, Sullivan DA, Morelli J, Ding J. Novel therapy to treat corneal epithelial defects: a hypothesis with growth hormone. Ocul Surf. 2015;13(3):204-12 e1. doi:10.1016/j.jtos.2014.12.005

3. Katzman LR, Jeng BH. Management strategies for persistent epithelial defects of the cornea. Saudi J Ophthalmol. 2014;28(3):168-172. doi:10.1016/j.sjopt.2014.06.011

4. Baum J. Thygeson lecture. Amniotic membrane transplantation: why is it effective? Cornea. 2002;21:339-341. doi:10.1097/00003226200205000-00001

5. Fernandes M, Sridhar MS, Sangwan VS, et al. Amniotic membrane transplantation for ocular surface reconstruction. Cornea. 2005;24:643-653. doi:10.1097/01.ico.0000151501.80952.c5

6. Prabhasawat P, Tesavibul N, Komolsuradej W. Single and multilayer amniotic membrane transplantation for persistent corneal epithelial defect with and without stromal thinning and perforation. $\mathrm{Br}$ J Ophthalmol. 2001;85:1455-1463. doi:10.1136/bjo.85.12.1455
7. Letko E, Stechschulte SU, Kenyon KR, et al. Amniotic membrane inlay and overlay grafting for corneal epithelial defects and stromal ulcers. Arch Ophthalmol. 2001;119:659-663. doi:10.1001/ archopht.119.5.659

8. Dua HS, Gomes JA, King AJ, et al. The amniotic membrane in ophthalmology. Surv Ophthalmol. 2004:49:51-77. doi:10.1016/j. survophthal.2003.10.004

9. Dua HS. Amniotic membrane transplantation. Br J Ophthalmol. 1999;83(6):748-752. doi:10.1136/bjo.83.6.748

10. Burman S, Tejwani S, Vemuganti GK, et al. Ophthalmic applications of preserved human amniotic membrane: a review of current indications. Cell Tissue Bank. 2004;5:161-175. doi:10.1023/B: CATB.0000046067.25057.0a

11. Thiex NW, Chames MC, Loch-Caruso RK. Tissue-specific cytokine release from human extra-placental membranes stimulated by lipopolysaccharide in a two-compartment tissue culture system. Reprod Biol Endocrinol. 2009;7:117. doi:10.1186/14777827-7-117

12. Kobayashi N, Kabuyama Y, Sasaki S, Kato K, Homma Y. Suppression of corneal neovascularization by culture supernatant of human amniotic cells. Cornea. 2002;21:62-67. doi:10.1097/ 00003226-200201000-00014

13. Solomon A, Wajngarten M, Alviano F, et al. Suppression of inflammatory and fibrotic responses in allergic inflammation by the amniotic membrane stromal matrix. Clin Exp Allergy. 2005;35:941-948. doi:10.1111/j.1365-2222.2005.02285.x

14. Kjaergaard N, Hein M, Hyttel L, et al. Antibacterial properties of human amnion and chorion in vitro. Eur J Obstet Gynecol Reprod Biol. 2001;94:224-229. doi:10.1016/S0301-2115(00)00345-6

15. de Rotth A. Plastic repair of conjunctival defects with fetal membranes. Arch Ophthalmol. 1940;23:522-525. doi:10.1001/ archopht.1940.00860130586006

16. Adds PJ, Hunt CJ, Dart JK. Amniotic membrane grafts, 'fresh' or frozen? A clinical and in vitro comparison. $\mathrm{Br} J$ Ophthalmol. 2001;85:905-907. doi:10.1136/bjo.85.8.905

17. Allen CL, Clare G, Stewart EA, et al. Augmented dried versus cryopreserved amniotic membrane as an ocular surface dressing. PLoS One. 2013;8(10):e78441. doi:10.1371/journal.pone.0078441

18. OmniLenz bespoke bandage contact lens; 2021. Available from: https://www.nu-vision.co.uk/omnilenz. Accessed March 28, 2021.

19. Tsai RJF, Tseng SCG. Effect of stromal inflammation on the outcome of limbal transplantation for corneal surface reconstruction. Cornea. 1995;14:439-449. doi:10.1097/00003226-199509000-00001

20. Kenyon KR, Berman M, Rose J, Gage J. Prevention of stromal ulceration in the alkali-burned rabbit cornea by glued-on contact lens. Invest Ophthalmol Vis Sci. 1979;18:570-587.

21. Khodadoust AA, Silverstein AM, Kenyon KR, Dowling JE. Adhesion of regenerating corneal epithelium. Am $J$ Ophthalmol. 1968;65:339-348. doi:10.1016/0002-9394(68)93082-1

22. Guo M, Grinnel F. Basement membrane and human epidermal differentiation in vitro. $J$ Invest Dermatol. 1989;93:372-378. doi:10.1016/ 0022-202X(89)90062-6

23. van Herendael BJ, Oberti C, Brosens I. Microanatomy of the human amniotic membranes. Am J Obstet Gynecol. 1978;131:872-880. doi:10.1016/S0002-9378(16)33135-0

24. Kheirkhah A, Casas V, Raju VK, et al. Sutureless amniotic membrane transplantation for partial limbal stem cell deficiency. $\mathrm{Am}$ J Ophthalmol. 2008;145:787-794. doi:10.1016/j.ajo.2008.01.009

25. Hick S, Demers PE, Brunette I, et al. Amniotic membrane transplantation and fibrin glue in the management of corneal ulcers and perforations: a review of 33 cases. Cornea. 2005;24:369-377. doi:10.1097/01.ico.0000151547.08113.d1

26. Ijiri S, Kobayashi A, Sugiyama K, et al. Evaluation of Visual acuity and color vision in normal human eyes with a sutureless temporary amniotic membrane patch. Am J Ophthalmol. 2007;144:938-942. doi:10.1016/j.ajo.2007.08.003 
27. Sheha H, Liang L, Li J, et al. Sutureless amniotic membrane transplantation for severe bacterial keratitis. Cornea. 2009;28:1118-1123. doi:10.1097/ICO.0b013e3181a2abad

28. Kheirkhah A, Johnson DA, Paranjpe DR, et al. Temporary sutureless amniotic membrane patch for acute alkaline burns. Arch Ophthalmol. 2008;126:1059-1066. doi:10.1001/archopht.126.8.1059

29. Shay E, Khadem JJ, Tseng SC. Efficacy and limitation of sutureless amniotic membrane transplantation for acute toxic epidermal necrolysis. Cornea. 2010;29:359-361. doi:10.1097/ICO.0b013e3181acf816

30. Shammas MC, Lai EC, Sarkar JS, et al. Management of acute Stevens-Johnson syndrome and toxic epidermal necrolysis utilizing amniotic membrane and topical corticosteroids. Am J Ophthalmol. 2010;149:203-213. doi:10.1016/j.ajo.2009.08.040

31. Kucukerdonmez C, Karalezli A, Akova YA, et al. Amniotic membrane transplantation using fibrin glue in pterygium surgery: a comparative randomised clinical trial. Eye (Lond). 2010;24:558-566. doi:10.1038/eye.2009.136
32. Sridhar MS, Bansal AK, Rao GN. Surgically induced necrotizing scleritis after pterygium excision and conjunctival autograft. Cornea. 2002;21:305-307. doi:10.1097/00003226-200204000-00013

33. Suri K, Kosker M, Raber IM, et al. Sutureless amniotic membrane ProKera for ocular surface disorders: short-term results. Eye Contact Lens. 2013;39(5):341-347. doi:10.1097/ICL.0b013e3182a2f8fa

34. Pachigolla G, Prasher P. Evaluation of the role of ProKera in the management of ocular surface and orbital disorders. Eye Contact Lens. 2009;35(4):172-175. doi:10.1097/ICL.0b013e3181a66a12
Clinical Ophthalmology

\section{Publish your work in this journal}

Clinical Ophthalmology is an international, peer-reviewed journal covering all subspecialties within ophthalmology. Key topics include: Optometry; Visual science; Pharmacology and drug therapy in eye diseases; Basic Sciences; Primary and Secondary eye care; Patient Safety and Quality of Care Improvements. This journal is indexed on PubMed

Submit your manuscript here: https://www.dovepress.com/clinical-ophthalmology-journal

\section{Dovepress}

Central and CAS, and is the official journal of The Society of Clinical Ophthalmology (SCO). The manuscript management system is completely online and includes a very quick and fair peer-review system, which is all easy to use. Visit http://www.dovepress.com/ testimonials.php to read real quotes from published authors. 